P.O. Kuzema, I.V. Laguta, O.N. Stavinskaya

\title{
TGA AND TPD MS STUDY OF SILICA-GELATIN MATERIALS
}

\author{
Chuiko Institute of Surface Chemistry of National Academy of Sciences of Ukraine \\ 17 General Naumov Str., Kyiv, 03164, Ukraine, E-mail: sci-worker@yandex.ua
}

Gelatin-based films with silica-to-gelatin weight ratio 1:5 or 8:5, containing either hydrophilic or hydrophilichydrophobic silica, have been prepared and studied by means of thermogravimetric analysis and temperatureprogrammed desorption mass spectrometry. It has been shown that silica presence has no effect on the mechanism of thermal decomposition of gelatin; however, it affects the kinetics of gelatin thermolysis both in vacuum and in air, including an increase in the activation energy of the volatile products formation at hydrophilic silica content about 17 wt. \%. Hydrophobization of silica surface as well as an increase in hydrophilic silica concentration in the film from 17 to $62 \mathrm{wt}$ \% decreases the activation energy of the volatile products formation during gelatin thermolysis. This effect is explained by reduced binding of gelatin with silica owing to either substitution of some surface silanol groups upon partial hydrophobization of silica, or their involving into interparticle rather than in silica-gelatin interactions at higher silica content.

Keywords: gelatin, mass spectrometry, silica, thermogravimetric analysis, thermolysis

\section{INTRODUCTION}

Gelatin is known to be widely used in pharmaceutical industry for the production of the preparations with prolonged action [1]. In many cases, however, pure gelatin hardly provides the necessary time for drug release. Moreover, because of high hygroscopicity and aging of gelatin, the related materials are unstable under wet conditions and at elevated temperature. Thus, it has been found that gelatin in capsules as well as gelatin coatings over tablets undergo conformational changes and cross-linking during their storage under wet conditions [2].

To increase the time of gelatin degradation and to slow down the drug desorption it is necessary to use the cross-linking agents [3]. Cross-linking processes in gelatin cause the formation of swollen rubberlike waterproof gelatin film resulting in reduced rate of drug dissolution in vitro [4]. Probably, this waterproof film acts as a barrier restraining the drug release.

Previously we have shown [5] that fumed silica may be used as a cross-linker owing to high concentration of surface $\equiv \mathrm{SiO}^{-}$and $\equiv \mathrm{SiOH}$ groups capable to interact electrostatically with positively charged parts of gelatin molecules and to form hydrogen bonds with carboxyl and amino groups of the polymer. The properties of such silicagelatin materials will depend on the quantity of silica embedded and on the nature of its surface. In this respect, it is of interest to study the influence of the concentration and modification of silica surface on thermal behaviour of gelatin-based materials.

\section{EXPERIMENTAL}

Fumed silica with a specific surface area of $200 \mathrm{~m}^{2} / \mathrm{g}$ (Kalush, Ukraine) was used as a hydrophilic nanofiller (A200). Hydrophobized nanofiller (AMT) was obtained via gas-phase treatment of A200 silica surface with trimethylchlorosilane (Kremnypolymer, Ukraine) in the reactor with a mixer at $250{ }^{\circ} \mathrm{C}$ (the reaction scheme is:

$\equiv \mathrm{Si}-\mathrm{OH}+\mathrm{ClSi}\left(\mathrm{CH}_{3}\right)_{3} \rightarrow \equiv \mathrm{Si}-\mathrm{O}-\mathrm{Si}\left(\mathrm{CH}_{3}\right)_{3}+\mathrm{HCl}$.

Partial trimethylsilylation (about $40 \%$ ) of silica surface was confirmed by means of IR spectroscopy. Gelatins from porcine skin (type A) were purchased from Sigma Co. Silica-gelatin films were prepared according to the following procedure. $5 \mathrm{ml}$ of distilled water were added into the glass with the appropriate quantity of silica and mixed with a magnetic stirrer for $15 \mathrm{~min}$. Also, $5 \mathrm{ml}$ of distilled water were added into another glass with the appropriate quantity of gelatin and mixed with a magnetic stirrer for $15 \mathrm{~min}$, after that the mixture was heated at $37-42^{\circ} \mathrm{C}$ until complete gelatin dissolution. Then the suspension of silica in water or $5 \mathrm{ml}$ of water (control) were added into gelatin solution and the mixture was stirred for $10 \mathrm{~min}$. To prepare gelatin or silica-gelatin films the portion of suspension $(2 \mathrm{ml})$ was poured out onto plastic substrate to form thin layer. The silica- 
to-gelatin weight ratio in final composites was either 1:5 or 8:5.

Thermogravimetric analysis (TGA) of gelatin and silica-gelatin materials was performed using a Derivatograph MOM Q-1500 (Paulik and Erdey, Hungary) in the $20-1000{ }^{\circ} \mathrm{C}$ interval of temperature. The analysis was run in air atmosphere, on thin films placed in alumina crucibles, at the heating rate of $10^{\circ} \mathrm{C} / \mathrm{min}$. Assessment of the kinetic parameters for individual stages of the gelatin thermolysis was performed by DTG curves treatment according to the graphical model [6], Friedman method [7], and the models of non-isothermal kinetics for chemical reactions of 1-3 order (MS) [8]. In particular, Friedman's procedure envisaged using of the following logarithmic differential equation:

$\ln (\mathrm{d} \alpha / \mathrm{d} t)=\ln k_{0}+n \ln (1--\alpha)-E /(R T)$,

where $\alpha$ is the conversion degree; $t$ - time, $\mathrm{s} ; k_{0}-$ pre-exponential factor, $\mathrm{s}^{-1} ; n$ - reaction order; $E-$ activation energy, $\mathrm{kJ} / \mathrm{mol} ; R$ - universal gas constant; $T$ - temperature, K. The plot $\ln (\mathrm{d} \alpha / \mathrm{d} t)$ vs. $1 / T$ gave a straight line from which the $E$ was determined, after that the plot $\ln (\mathrm{d} \alpha / \mathrm{d} t)+E /(R T)$ vs. $\ln (1-\alpha)$ gave also a straight line from which the $n$ and $k_{0}$ values were found. The equations used for determination of kinetic parameters by the MS method were as follows: $\mathrm{d} \alpha / \mathrm{d} t=k \alpha(t)^{\mathrm{n}}$, where $k=k_{0} \exp [-E /(R T)] ; \quad \alpha(t)=\exp [-\varphi(t)] \quad(n=1)$; $\alpha(t)=1 /[1+\varphi(t)] \quad(n=2) ; \quad \alpha(t)=1 /[1+2 \varphi(t)]^{1 / 2} \quad(n=3) ;$ $\varphi(t) \approx R T_{\mathrm{m}}{ }^{2} k_{0} \exp [-E /(R T)] /(E \beta) ; T_{\mathrm{m}}-$ temperature at peak maximum, $\mathrm{K} ; \beta$ - heating rate, $\mathrm{K} / \mathrm{s}$.

The samples obtained were also studied by means of temperature-programmed desorption mass spectrometry (TPD MS) (a MX 7304A mass spectrometer, Selmi, Ukraine) in the temperature interval of $20-800^{\circ} \mathrm{C}$ at heating rate $10^{\circ} \mathrm{C} / \mathrm{min}$, $\mathrm{m} / \mathrm{z}$ range $10-190 \mathrm{Da}$. Analysis of volatile products formed during the samples heating under vacuum was performed according to the following procedure [8]. The samples ( 1 $\mathrm{mg}$ each) were placed in a quartz-molybdenum tube and evacuated until the pressure reached $\sim 10^{-1} \mathrm{~Pa}$. Then the tube was attached to the inlet system of the mass spectrometer and the linear heating was applied. For the characteristic components of the mass spectra for the main volatile products of the samples thermolysis the appropriate curves were built. In order to derive kinetic parameters of gelatin thermal decomposition, mathematical treatment of some curves was performed. The models of non-isothermal kinetics used are given above (MS method), and the principles of mass spectrometric curves treatment applied are described in detail elsewhere [8].

\section{RESULTS AND DISCUSSION}

The results of thermogravimetric analysis are given in Fig. 1. The process of pure gelatin weight loss at heating (Fig. 1, curve 1) can be tentatively divided into the following stages (Fig. 2): $30-200{ }^{\circ} \mathrm{C}$ (stage I), $200-520^{\circ} \mathrm{C}$ (stage II), and $520-780^{\circ} \mathrm{C}$ (stage III).

Stage I is associated with removal of physically bound water from gelatin sample. This process is accompanied by a slight endo-effect (Fig. $1 b$, curve 1), and its activation energy is about $50-55 \mathrm{~kJ} / \mathrm{mol}$ (Table 1). According to the data from the literature [9], thermal decomposition of gelatin starts upon transition to high-elasticity state $\left(\approx 210^{\circ} \mathrm{C}\right)$, and thermal oxidation is the most rapid upon transition to plastic state (higher than $230{ }^{\circ} \mathrm{C}$ ) (stage II). Mass spectrometric data suggests that during vacuum thermal decomposition of gelatin at the temperature interval of stage II mainly $\mathrm{H}_{2} \mathrm{O}, \mathrm{NH}_{3}, \mathrm{HCN}, \mathrm{C}_{2} \mathrm{H}_{4}, \mathrm{CO}_{2}, \mathrm{CH}_{4}$ are formed. Under air atmosphere the formation of oxygen-containing species (aldehydes, ketones, carboxylic acids) is also possible. The distinct exoeffect during the process of gelatin thermal degradation is observed after $300{ }^{\circ} \mathrm{C}$ (Fig. $1 \mathrm{~b}$, curve 1) and it is probably related to the ending of endothermic process of structural water removal which, up to the temperature $300^{\circ} \mathrm{C}$, compensates exo-effect of the polymer oxidation process. According to the data from Table 1, the mean values of the activation energy (by the Friedman and MS methods) for the main processes of volatile products removal, as a result of gelatin thermaloxidative degradation at the temperature range of the stage II, are $\sim 110$ and $150 \mathrm{~kJ} / \mathrm{mol}$ (the peaks 3 and 4, respectively, Fig. 2). Thermal degradation of gelatin at the stage III is accompanied by a few distinct exo-effects indicating the passage of several (at least three) processes. The averaged effective activation energy is $262 \mathrm{~kJ} / \mathrm{mol}$. The process of gelatin thermal degradation with the formation of volatile products ends at $780^{\circ} \mathrm{C}$. The total weight loss is $98.5 \%$.

The presence of nanosilica in gelatin matrix slightly decreases the initial temperature of gelatin thermal degradation (Fig. 1, curves 2-4). This is probably due to loosening of the polymer structure, which facilitates the oxygen penetration into the polymer matrix. The temperature of maximum rate 
of weight loss at the stage II is also decreased, however, the activation energy (by the average readings of the Friedman and MS methods, Table 1) slightly increases in the case of A200-gelatin (1:5) sample, and decreases in the case of AMT-gelatin (1:5) and A200-gelatin (8:5) samples. The latter could be explained by stronger interaction of gelatin molecules with the pristine in

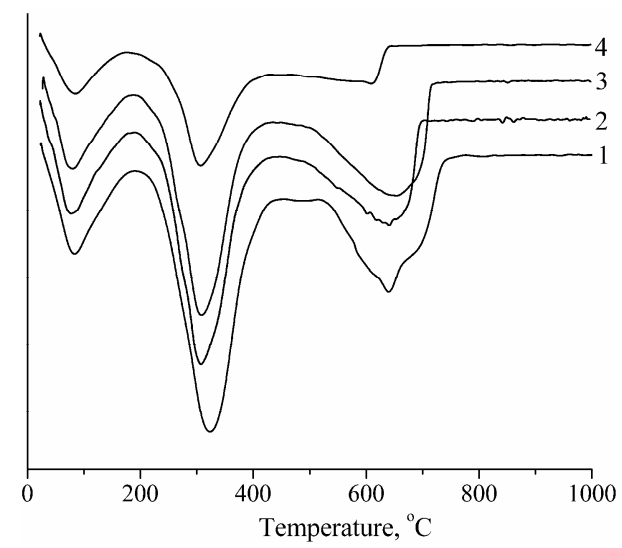

$a$

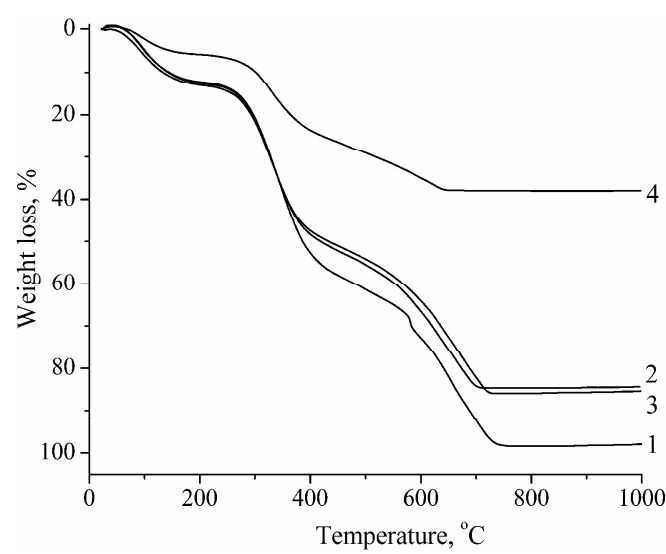

c

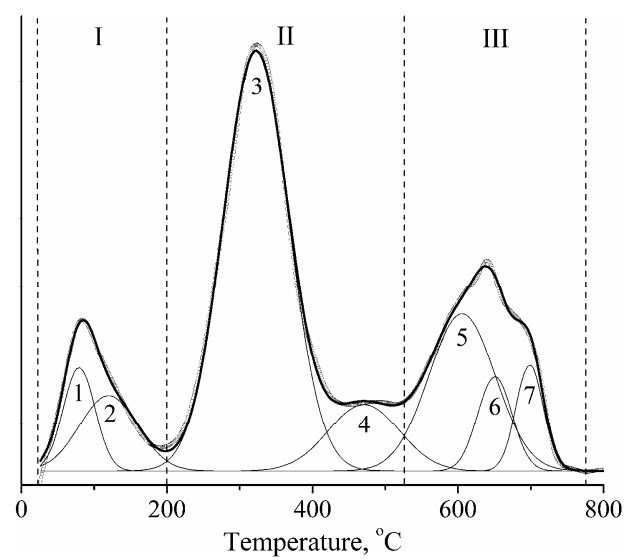

comparison with modified silica surface, interparticle binding being prevailed over silicagelatin binding as the silica concentration increases. The appearance of distinct broad exoeffect with $T_{\max } \approx 350{ }^{\circ} \mathrm{C}$ on the DTA curve 4 in Fig. $1 b$ corresponds to the water removal from the silica surface in the silica-gelatin (8:5) film as a result of silanol groups condensation.

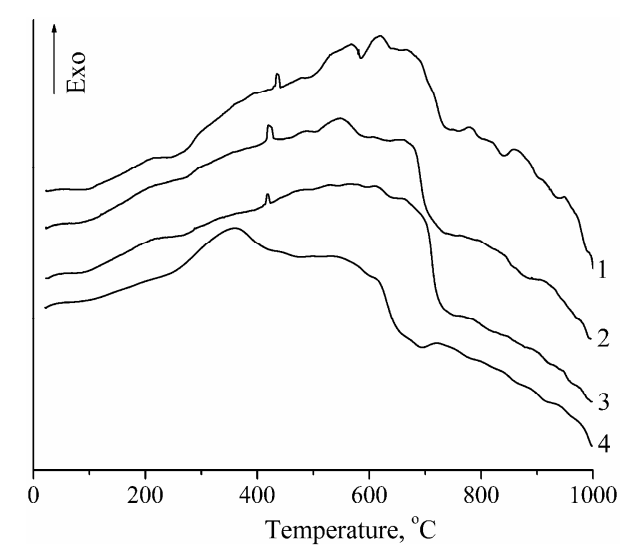

b

Fig. 1. DTG (a), DTA (b), and TG (c) curves for: 1 - pure gelatin,

2 - A200-gelatin (1:5), 3 - AMT-gelatin (1:5), 4 - A200-gelatin (8:5)
Fig. 2. Gauss splitting of DTG curve for thermal degradation of pure gelatin (points - experiment, thick curve is the sum of model (thin) curves) 
Table 1. Kinetic parameters for the formation of volatile products of silica-gelatin films thermolysis, derived from the TGA data

\begin{tabular}{|c|c|c|c|c|c|c|c|c|c|c|c|c|}
\hline \multirow{2}{*}{ Sample } & \multirow{2}{*}{$\begin{array}{c}\text { The compound (by the data of vacuum } \\
\text { thermal decomposition) }\end{array}$} & \multirow{2}{*}{ Peak No } & \multirow{2}{*}{$\begin{array}{c}T_{\max }, \\
{ }^{\circ} \mathbf{C}\end{array}$} & \multicolumn{3}{|c|}{$E_{\mathrm{a}}, \mathrm{kJ} / \mathrm{mol}$} & \multicolumn{2}{|c|}{$k_{0}, \mathrm{~s}^{-1}$} & \multicolumn{2}{|l|}{$n$} & \multicolumn{2}{|c|}{$w, \%$} \\
\hline & & & & Graphical & Friedman & MS & Friedman & MS & Friedman & MS & Graphical & MS \\
\hline \multirow{10}{*}{$\begin{array}{l}\text { Pure } \\
\text { gelatin }\end{array}$} & $\mathrm{H}_{2} \mathrm{O}$ & 1 & 79 & 45 & 40 & & & & & & 5.8 & \\
\hline & $\mathrm{H}_{2} \mathrm{O}$ & 2 & 120 & 31 & 70 & & & & & & 7.7 & \\
\hline & & $1+2$ (I) & 83 & 38 & 55 & 63 & $1.3 \times 10^{4}$ & $2.1 \times 10^{6}$ & $\mathbf{3 5 . 4 2}$ & 3 & & 9.6 \\
\hline & $\mathrm{H}_{2} \mathrm{O}, \mathrm{NH}_{3}, \mathrm{HCN}, \mathrm{C}_{2} \mathrm{H}_{4}, \mathrm{CO}_{2}$ & 3 & 322 & 62 & 115 & 102 & & $1.2 \times 10^{6}$ & & 2 & 48.5 & 32.8 \\
\hline & $\mathrm{CH}_{4}$ & 4 & 471 & 88 & 77 & 220 & & $3.5 \times 10^{12}$ & & 2 & 8.5 & 6.7 \\
\hline & & $3+4$ (II) & 323 & 75 & 96 & 102 & $1.2 \times 10^{6}$ & $1.2 \times 10^{6}$ & 5.63 & 2 & & \\
\hline & $\mathrm{HCN}$ & 5 & 606 & 132 & 86 & 250 & & $7.6 \times 10^{12}$ & & 1 & 18.7 & 10.7 \\
\hline & $\mathrm{HCN}$ & 6 & 651 & 288 & 44 & 270 & & $1.4 \times 10^{13}$ & & 1 & 5.7 & 20.2 \\
\hline & $\mathrm{HCN}$ & 7 & 698 & 399 & 604 & 285 & & $1.0 \times 10^{13}$ & & 1 & 5.1 & 20.0 \\
\hline & & $5+6+7$ (III) & 640 & 273 & 245 & 268 & $9.2 \times 10^{12}$ & $1.2 \times 10^{13}$ & 2.56 & 1 & & \\
\hline \multirow{10}{*}{$\begin{array}{l}\text { A200- } \\
\text { gelatin } \\
(1: 5)\end{array}$} & $\mathrm{H}_{2} \mathrm{O}$ & 1 & 73 & 39 & 34 & & & & & & 7.6 & \\
\hline & $\mathrm{H}_{2} \mathrm{O}$ & 2 & 112 & 26 & 71 & & & & & & 8.2 & \\
\hline & & $1+2(I)$ & 77 & 33 & 53 & 68 & $0.7 \times 10^{4}$ & $8.1 \times 10^{6}$ & 27.80 & 3 & & 8.8 \\
\hline & $\mathrm{H}_{2} \mathrm{O}, \mathrm{NH}_{3}, \mathrm{HCN}, \mathrm{C}_{2} \mathrm{H}_{4}, \mathrm{CO}_{2}$ & 3 & 310 & 58 & 102 & 105 & & $2.3 \times 10^{6}$ & & 2 & 40.8 & 41.3 \\
\hline & $\mathrm{CH}_{4}$ & 4 & 483 & 44 & 94 & 218 & & $3.3 \times 10^{12}$ & & 2 & 18.2 & 7.8 \\
\hline & & $3+4$ (II) & 308 & 51 & 98 & 134 & $2.0 \times 10^{6}$ & $2.3 \times 10^{6}$ & 4.94 & 2 & & \\
\hline & $\mathrm{HCN}$ & 5 & 595 & 128 & 46 & 250 & & $1.8 \times 10^{13}$ & & 1 & 14.8 & 8.6 \\
\hline & $\mathrm{HCN}$ & 6 & 641 & 257 & 35 & 262 & & $1.3 \times 10^{13}$ & & 1 & 6.9 & 12.4 \\
\hline & $\mathrm{HCN}$ & 7 & 672 & 460 & 688 & 275 & & $1.0 \times 10^{13}$ & & 1 & 3.5 & 21.1 \\
\hline & & $5+6+7$ (III) & 628 & 282 & 256 & 262 & $3.8 \times 10^{12}$ & $1.4 \times 10^{13}$ & 1.03 & 1 & & \\
\hline \multirow{10}{*}{$\begin{array}{l}\text { AMT- } \\
\text { gelatin } \\
(1: 5)\end{array}$} & $\mathrm{H}_{2} \mathrm{O}$ & 1 & 67 & 37 & 26 & & & & & & 8.3 & \\
\hline & $\mathrm{H}_{2} \mathrm{O}$ & 2 & 114 & 32 & 68 & & & & & & 7.3 & \\
\hline & & $1+2$ (I) & 68 & 35 & 47 & 63 & $1.3 \times 10^{3}$ & $4.6 \times 10^{6}$ & 26.29 & 3 & & 10.9 \\
\hline & $\mathrm{H}_{2} \mathrm{O}, \mathrm{NH}_{3}, \mathrm{HCN}, \mathrm{C}_{2} \mathrm{H}_{4}, \mathrm{CO}_{2}$ & 3 & 310 & 56 & 90 & 105 & & $2.5 \times 10^{6}$ & & 2 & 40.1 & 29.0 \\
\hline & $\mathrm{CH}_{4}$ & 4 & 471 & 48 & 110 & 203 & & $1.6 \times 10^{11}$ & & 2 & 14.3 & 6.7 \\
\hline & & $3+4$ (II) & 308 & 52 & 100 & 105 & $1.8 \times 10^{6}$ & $2.5 \times 10^{6}$ & 4.94 & 2 & & \\
\hline & $\mathrm{HCN}$ & 5 & 595 & 118 & & 250 & & $1.6 \times 10^{13}$ & & 1 & 16.0 & 25.7 \\
\hline & $\mathrm{HCN}$ & 6 & 642 & 235 & & 266 & & $1.3 \times 10^{13}$ & & 1 & 7.3 & 17.2 \\
\hline & $\mathrm{HCN}$ & 7 & 682 & 401 & & 280 & & $8.4 \times 10^{12}$ & & 1 & 6.9 & 10.5 \\
\hline & & $5+6+7$ (III) & 637 & 251 & 268 & 265 & $2.8 \times 10^{12}$ & $1.3 \times 10^{13}$ & 0.79 & 1 & & \\
\hline \multirow{10}{*}{$\begin{array}{l}\text { A200- } \\
\text { gelatin } \\
(8: 5)\end{array}$} & $\mathrm{H}_{2} \mathrm{O}$ & 1 & 73 & 42 & 37 & & & & & & 8.6 & \\
\hline & $\mathrm{H}_{2} \mathrm{O}$ & 2 & 107 & 37 & 79 & & & & & & 7.2 & \\
\hline & & $1+2$ (I) & 82 & 40 & 58 & 71 & $1.8 \times 10^{5}$ & $1.1 \times 10^{7}$ & 23.98 & 3 & & 17.0 \\
\hline & $\mathrm{H}_{2} \mathrm{O}, \mathrm{NH}_{3}, \mathrm{HCN}, \mathrm{C}_{2} \mathrm{H}_{4}, \mathrm{CO}_{2}$ & 3 & 311 & 75 & & 101 & & $1,2 \times 10^{6}$ & & 2 & 24.8 & 38.5 \\
\hline & $\mathrm{CH}_{4}$ & 4 & 361 & 30 & & 220 & & $6,8 \times 10^{13}$ & & 2 & 37.2 & 9.0 \\
\hline & & $3+4$ (II) & 307 & 53 & 81 & 101 & $5.7 \times 10^{5}$ & $1.2 \times 10^{6}$ & 4.59 & 2 & & \\
\hline & $\mathrm{HCN}$ & 5 & 525 & 101 & & 234 & & $2.9 \times 10^{13}$ & & 1 & 12.3 & 4.5 \\
\hline & $\mathrm{HCN}$ & 6 & 583 & 223 & & 253 & & $6.2 \times 10^{13}$ & & 1 & 6.4 & 9.5 \\
\hline & $\mathrm{HCN}$ & 7 & 612 & 433 & & 260 & & $1.4 \times 10^{13}$ & & 1 & 3.5 & 21.5 \\
\hline & & $5+6+7$ (III) & 543 & 252 & 273 & 249 & $1.5 \times 10^{15}$ & $3.5 \times 10^{13}$ & 1.17 & 1 & & \\
\hline
\end{tabular}

$E_{\mathrm{a}}$ - activation energy; $k_{0}$ - pre-exponential factor; $n$ - reaction order; $w$ - weight coefficient 
At the stage III the influence of silica is characterized by smearing of peaks on DTG and DTA curves for gelatin thermal degradation (Fig. 1, curves 2-4), in all cases the process of weight loss for the films being ended at the temperature less than that in the case of pure gelatin, indicating that the structure loosening by the filler leads to the acceleration of the polymer thermal degradation. As the silica concentration increases, the ending temperature of gelatin degradation (accompanied by the volatile products removal) decreases. Analysis of the results of kinetic parameters calculation (average readings of Table 1) reveals a slight change in the effective
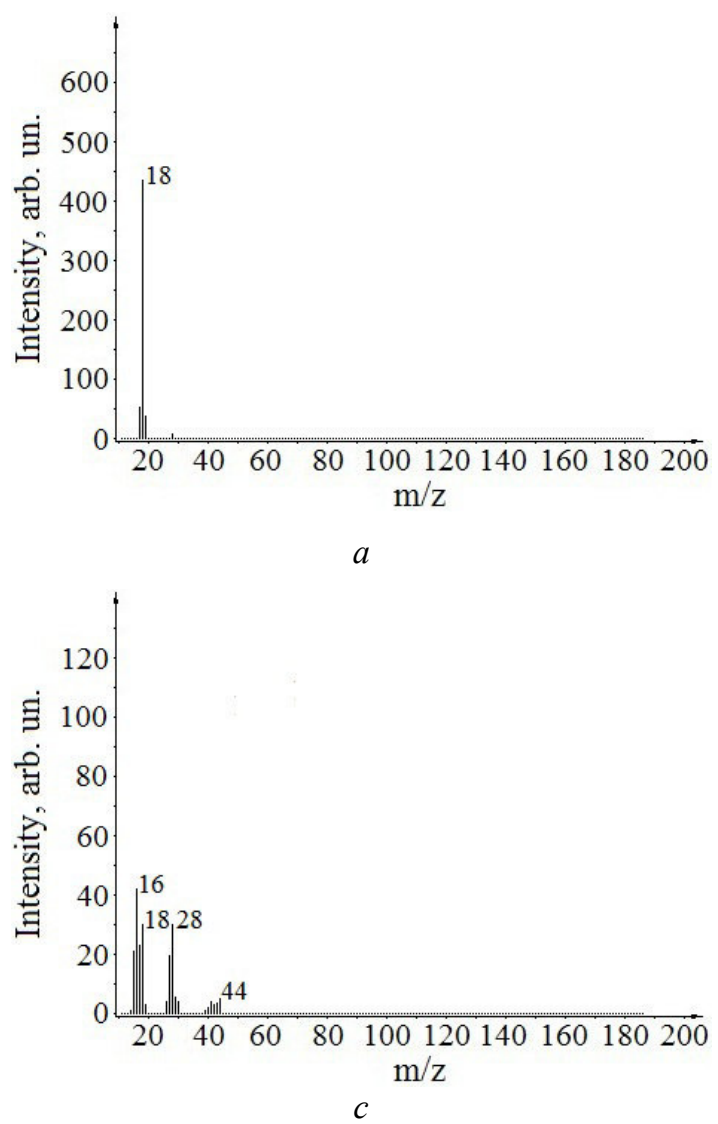

activation energy for the process of gelatin thermal degradation at the stage III, which is $267 \mathrm{~kJ} / \mathrm{mol}$ (A200-gelatin, 1:5), $261 \mathrm{~kJ} / \mathrm{mol}$ (AMT-gelatin, $1: 5$ ), and $258 \mathrm{~kJ} / \mathrm{mol}$ (A200-gelatin, 8:5). Comparison of the calculated and experimental values of char residues indicates the complete degradation of the polymer as a result of the films thermolysis.

Mass spectra of volatile products of pure gelatin vacuum thermal decomposition at various temperatures are shown in Fig. 3. The thermograms for some characteristic ions are given in Fig. 4.
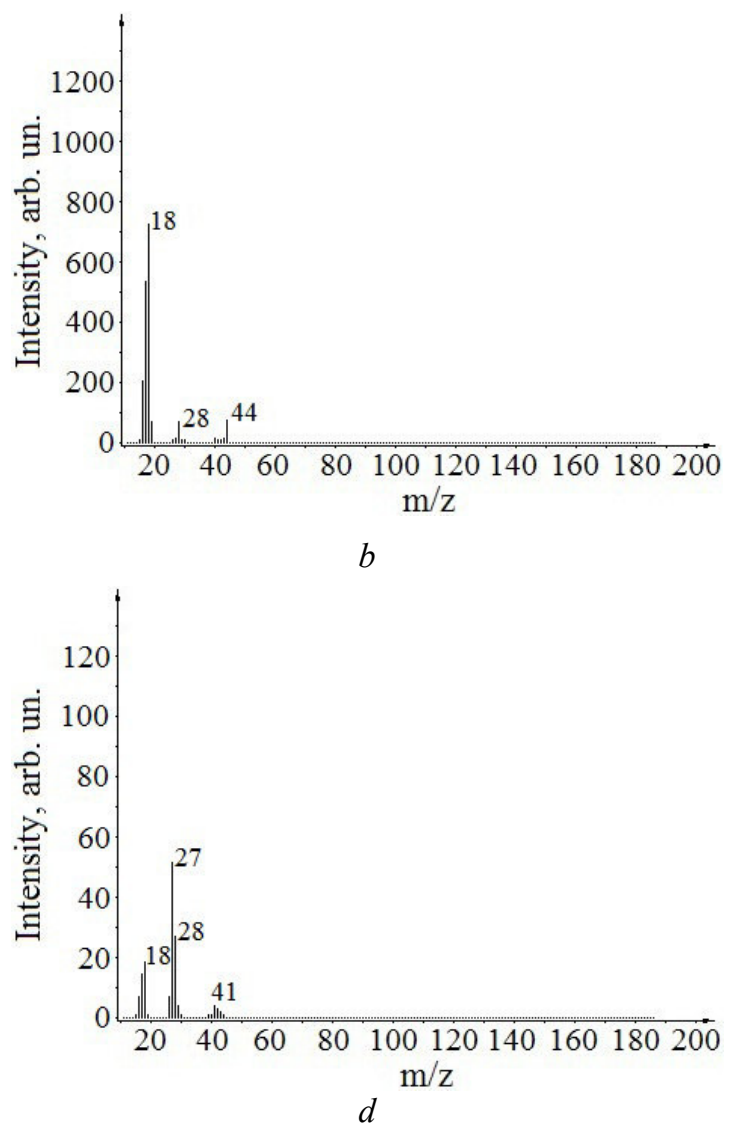

Fig. 3. Mass spectra of volatile products of gelatin thermolysis at $94,261,511$, and $720^{\circ} \mathrm{C}$ ( $a$ - $d$, respectively)

According to the analysis of the thermograms for the main volatile products formation, the process of gelatin vacuum thermal decomposition can be tentatively divided into the following stages:

1) $T \approx 25-170{ }^{\circ} \mathrm{C}$. Removal of the compounds with $m / z \quad 16-18, \quad 26-28-T_{\max } \approx 100-110^{\circ} \mathrm{C}$ (Fig. $4 a, b$ ).

2) $\quad T \approx 170-490^{\circ} \mathrm{C}$. Evolution of the products with: $m / z \quad 18 \quad\left(T_{\max } \sim 240^{\circ} \mathrm{C}\right), \quad 16$ and 17 ,
$T_{\max } \sim 260^{\circ} \mathrm{C}$ (Fig. $4 a, b$ ); $\mathrm{m} / \mathrm{z} \quad 26-28$ and 41 (Fig. $4 b, c$ ), $T_{\max }: 1-260,2-330,3-430{ }^{\circ} \mathrm{C}$; $m / z 44\left(T_{\max }: 1-260,2-300{ }^{\circ} \mathrm{C}\right.$, Fig. $\left.4 c\right) ; m / z 15$ and $16\left(T_{\max } \sim 410^{\circ} \mathrm{C}\right.$, Fig. $\left.4 c\right)$.

3) $T \approx 490-800{ }^{\circ} \mathrm{C}$. Proceeding removal of volatile products with $m / z 15$ and 16 (Fig. 4 c), 27, $T_{\max } \sim 700-720^{\circ} \mathrm{C}$ (Fig. 4 b).

Interpretation of the characteristic signals in the mass spectra suggests that the most probable 
volatile products of gelatin thermolysis are: $\mathrm{CH}_{4}$ $(\mathrm{m} / \mathrm{z} 15$ and 16$) ; \mathrm{NH}_{3}(\mathrm{~m} / \mathrm{z} 16$ and 17$) ; \mathrm{H}_{2} \mathrm{O}(\mathrm{m} / z 17$ and 18); $\mathrm{HCN}(m / z ~ 27) ; \mathrm{C}_{2} \mathrm{H}_{4}$ and, apparently,

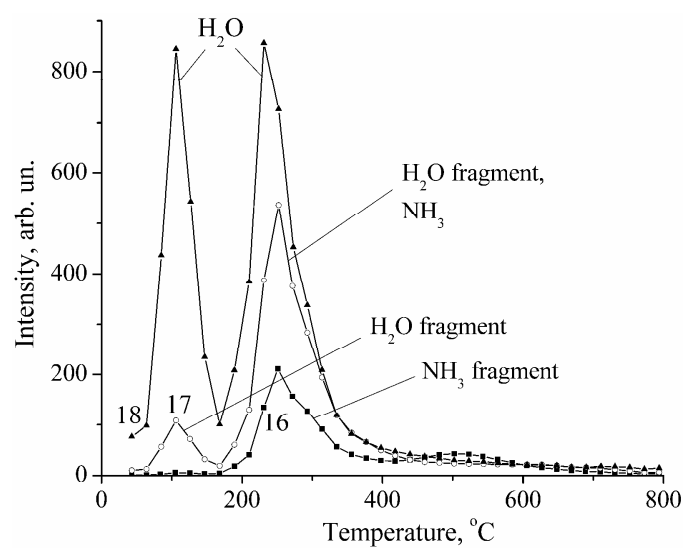

$a$

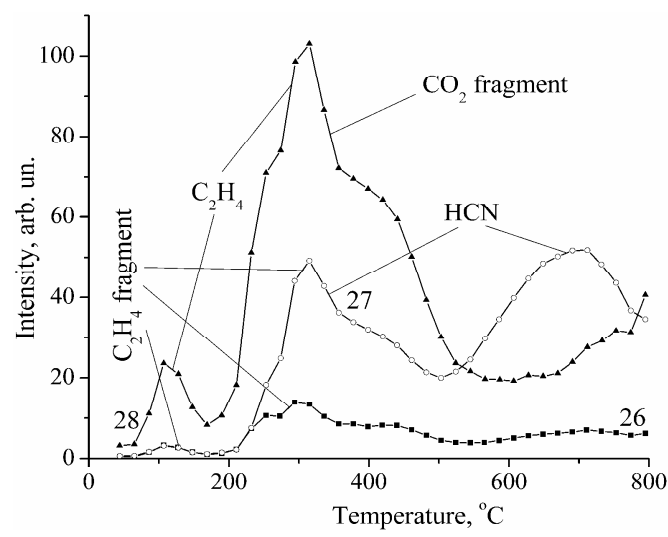

$b$

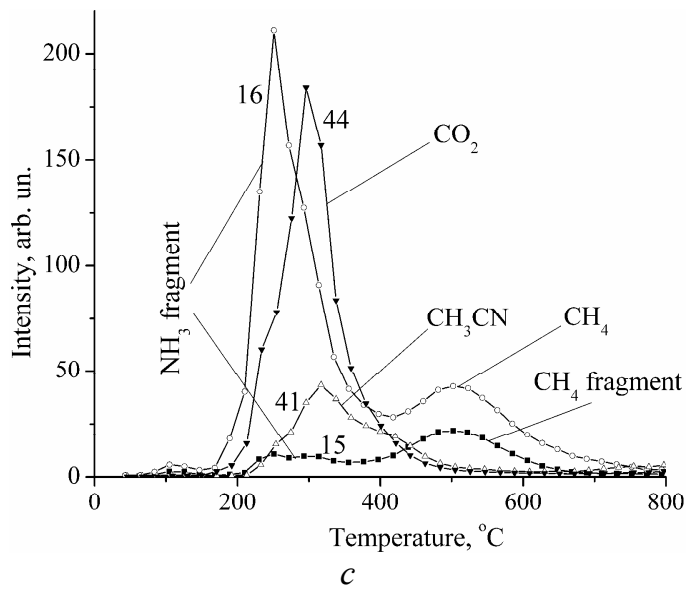

Fig. 4. Thermograms for the main volatile products of gelatin thermolysis

Based on the results of volatile products identification as well as on the analysis of the stage sequence of the main volatile products of gelatin thermolysis, it is suggested that the following other unsaturated hydrocarbons $(\mathrm{m} / \mathrm{z} 26,27$, and 28); nitrogen-containing organic compounds, including $\mathrm{CH}_{3} \mathrm{CN}(\mathrm{m} / \mathrm{z} 41) ; \mathrm{CO}_{2}(\mathrm{~m} / \mathrm{z} 44)$.

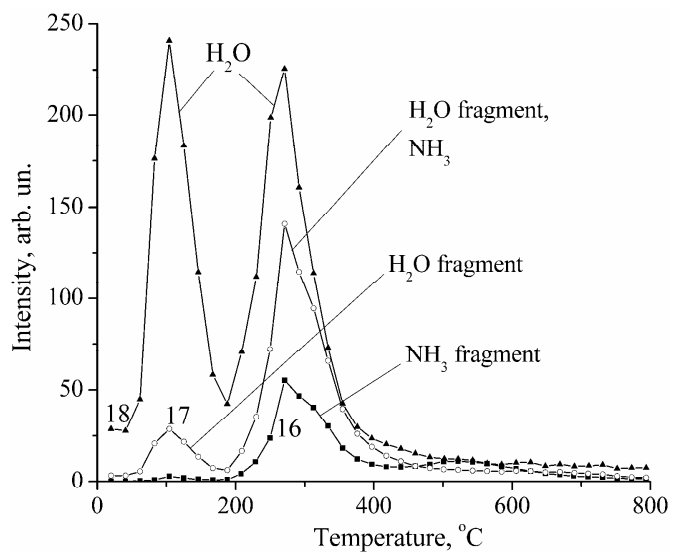

$a$

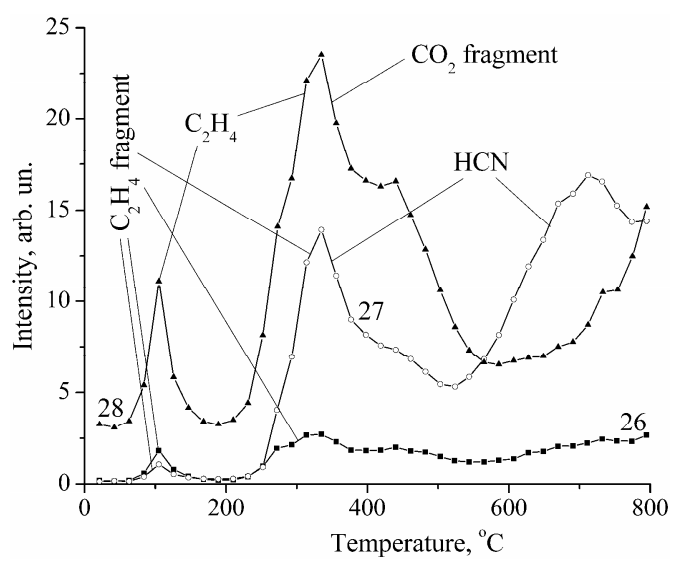

$b$

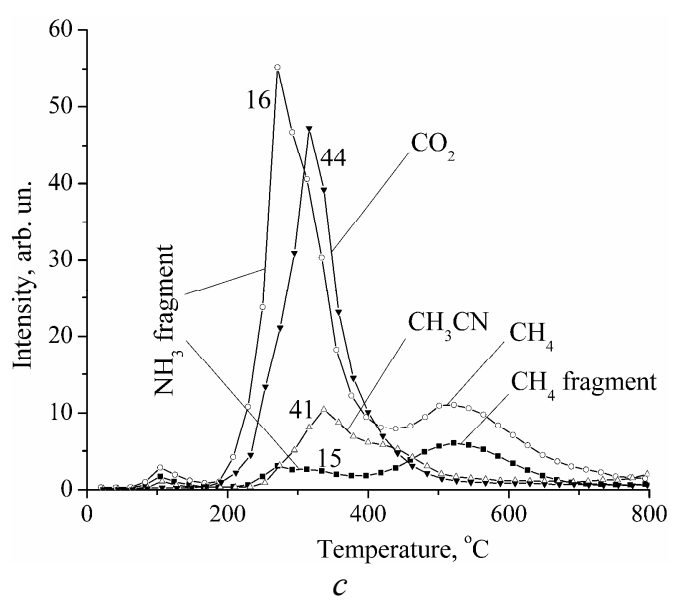

Fig. 5. Thermograms for the main volatile products of A200-gelatin (1:5) thermolysis

thermostimulated chemical processes are most likely to occur. The first stage is characterized by the removal of physically adsorbed water (first maximum on the curves for $\mathrm{m} / \mathrm{z} 17$ and 18 , 
Fig. $4 a$ ) as well as the formation of hydrocarbons $(\mathrm{m} / \mathrm{z}$ 26-28, Fig. $4 \mathrm{~b})$ in small quantity. The second stage proceeds with the removal of bound water (second maximum on the curves for $\mathrm{m} / z 17$ and 18, Fig. $4 a$ ), whose presence in gelatin was confirmed by many researchers (see, for instance, [10-12]), ammonia (maxima on the curves for $m / z 16$ and 17,
Fig. $4 a$ ), hydrocarbons and nitrogen-containing organic compounds $(\mathrm{m} / \mathrm{z} 15,16,26-28$, and 41$)$. This is actually the primary stage of gelatin vacuum thermal decomposition which ends at the third stage mainly with $\mathrm{HCN}$ removal. The formation of the above-mentioned compounds one may describe with the following schematic reactions:

$1^{\mathrm{A}}$

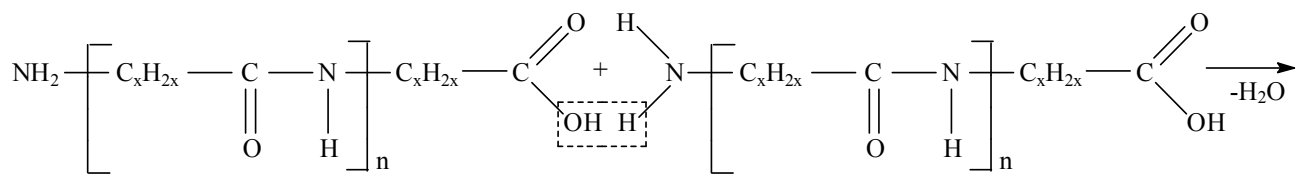

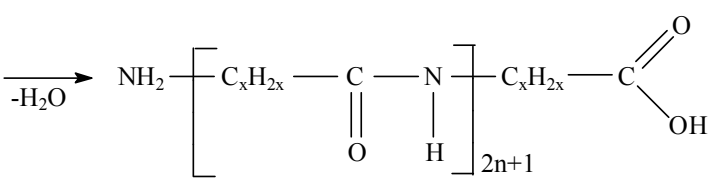

$1^{\mathrm{B}}$
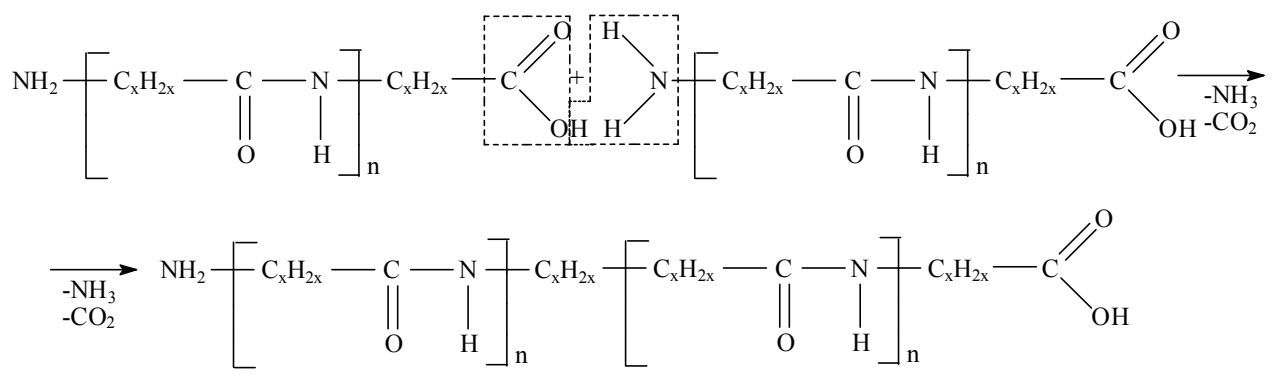

2

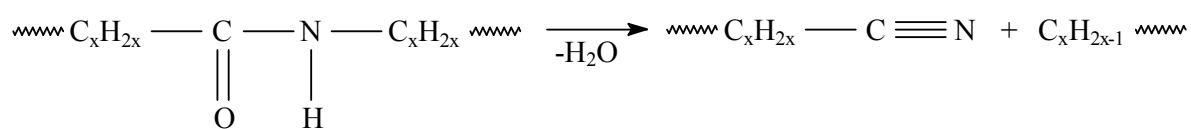

3
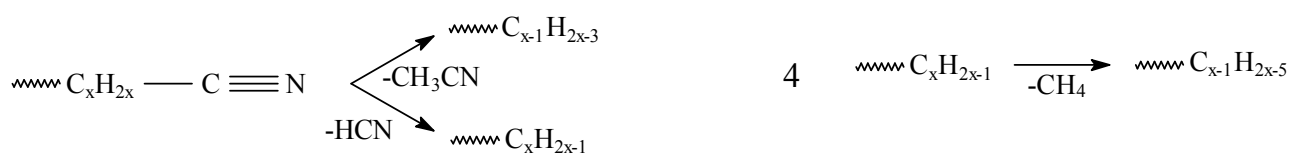

In general, the formation of volatile products of gelatin thermal decomposition at the second and the third stages may be schematically described with the reactions $5-7$ :

5

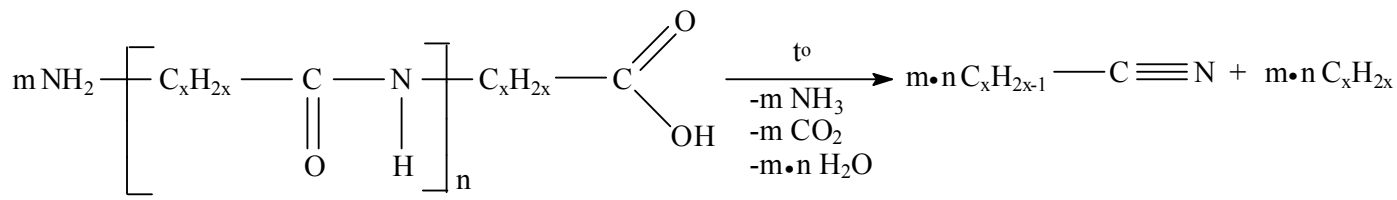

6

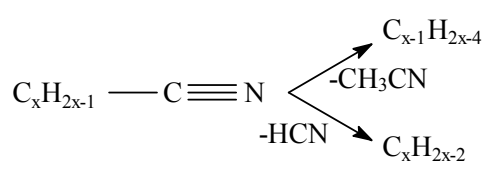

The mechanism of thermolysis in the case of A200-gelatin (1:5) (Fig. 5), AMT-gelatin (1:5) (Fig. 6), and A200-gelatin (8:5) (Fig. 7) films is the same as that for pure gelatin.
The data derived from the mathematical treatment of the thermograms for the main volatile products of gelatin (an example for the compound with $m / z 27$ is shown in Fig. 8) and silica-gelatin 
films thermolysis are given in Table 2. In general, the effect of silica is characterized by an increase in the activation energy of formation of the main volatile products of gelatin thermolysis, by
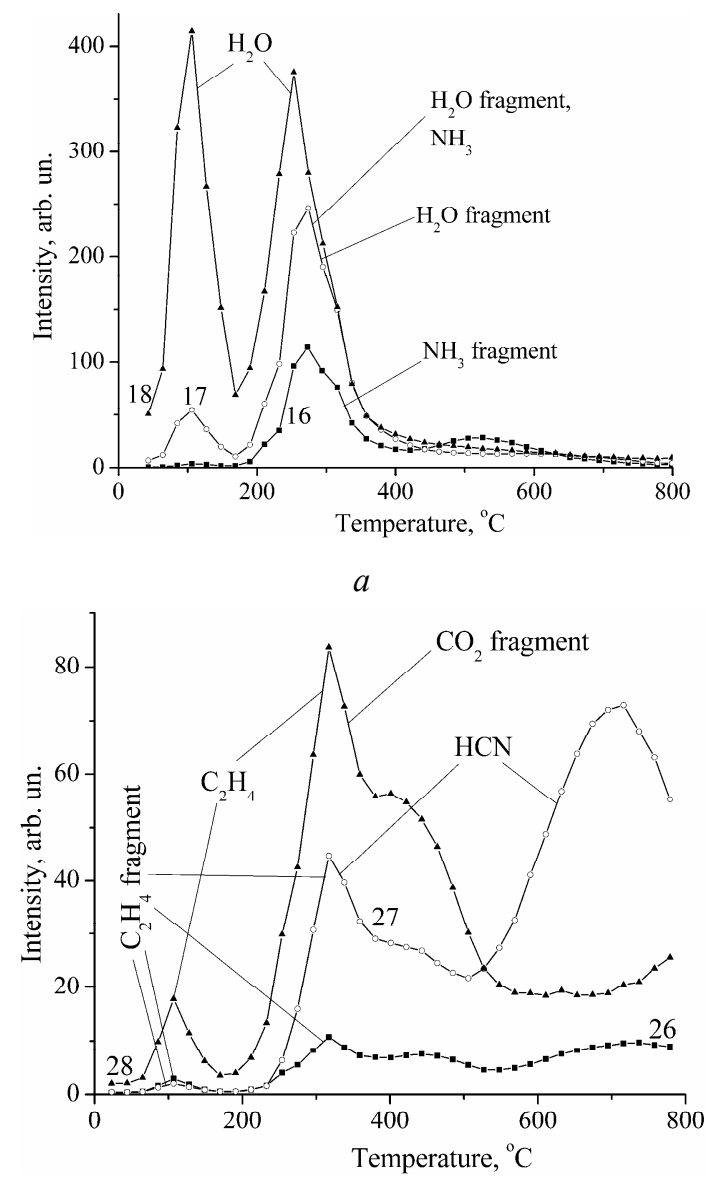

$b$

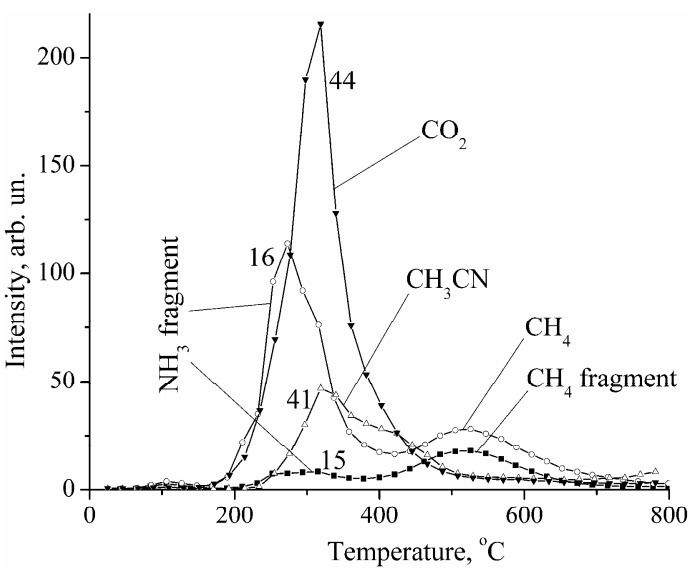

$c$

Fig. 6. Thermograms for the main volatile products of AMT-gelatin (1:5) thermolysis widening of peaks on the thermograms, and by change in contribution of individual stages into the overall process.

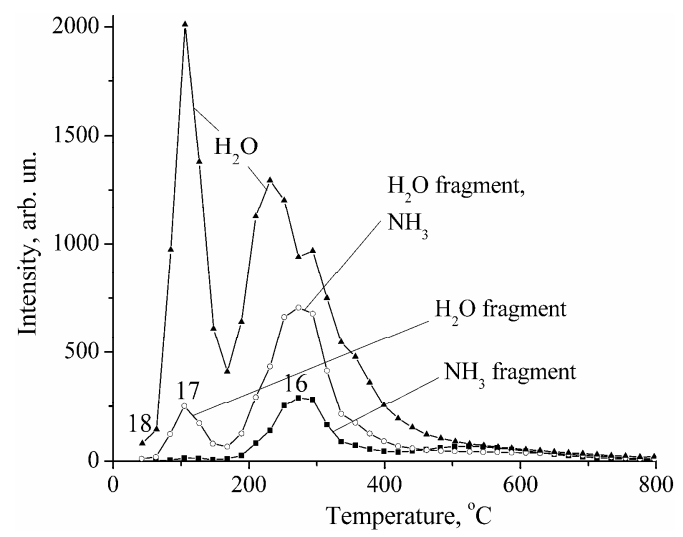

$a$

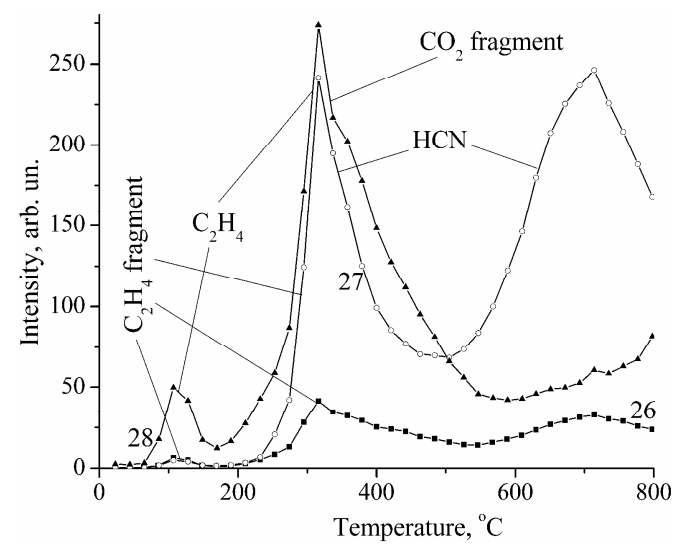

$b$

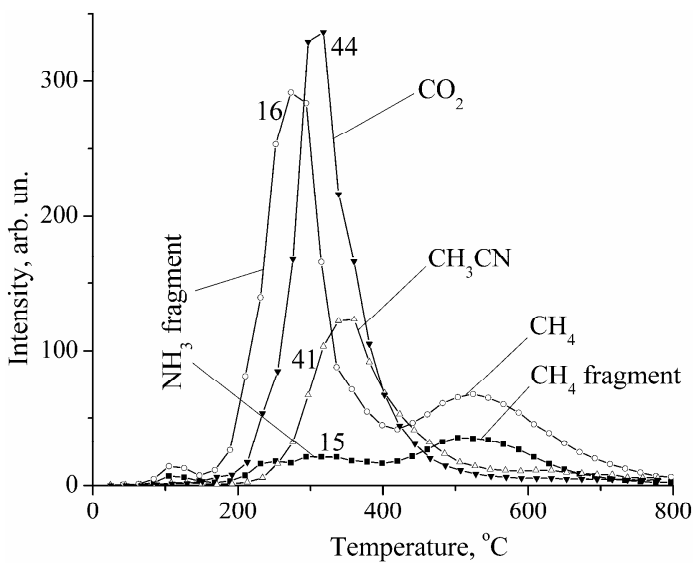

$c$

Fig. 7. Thermograms for the main volatile products of A200-gelatin (8:5) thermolysis 


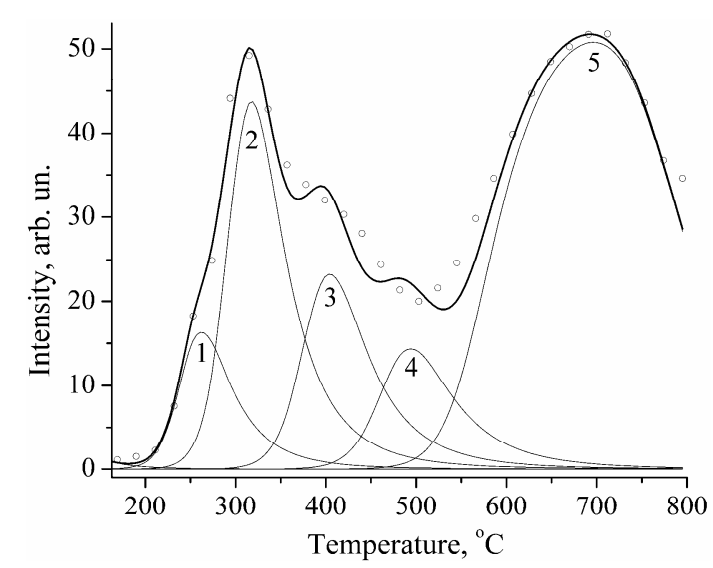

Fig. 8. An example of mathematical treatment of the thermogram $(\mathrm{m} / \mathrm{z} 27)$ using the models of nonisothermal chemical reactions of 3-rd order for pure gelatin sample (points - experiment, thick curve is the sum of model (thin) curves)

An analysis of the data in Table 2 has shown that there are some notable differences in the thermal behaviour of pure gelatin and its films with silica. Comparing the profile of thermograms for the samples of pure gelatin and the composite A200-gelatin (1:5) one should note a slight reduction of the second peak on the curve for the compound with $m / z 18$, which could be explained by the additional contribution of physically bound water, desorbing from the surface of silica filler, into the first peak on the thermogram (Fig. $5 a$ ). The same effect is also observed in the case of AMT-gelatin (1:5) composite (Fig. $6 a$ ). As silica contents grows (the composite A200-gelatin, 8:5), the second peak of water removal widens and splits (Fig. $7 \mathrm{a}$ ) due to removal of various forms of structural water from the silica surface. The highest increase in the activation energy of volatile products formation is observed for the composite A200-gelatin (1:5). It is associated with inhibiting effect of the surface: gelatin molecules bind with silica surface. In the case of modified silica and with an increase in pristine silica content the activation energies somewhat decrease (in comparison with those for the composite A200-gelatin, 1:5) because in the first case the gelatin interaction with partially hydrophobized silica surface is weaker and the macromolecules are more labile; in the second case probably silica particles bind more readily between each other rather than with the polymer molecules.

Table 2. Kinetic parameters for the formation of volatile products of silica-gelatin films thermolysis, derived from the TPD MS data

\begin{tabular}{|c|c|c|c|c|c|c|c|}
\hline Sample & Identified compound & Peak No & $n$ & $T_{\max },{ }^{\circ} \mathrm{C}$ & $E_{\mathrm{a}}, \mathrm{kJ} / \mathrm{mol}$ & $k_{0} \times 10^{-13}, \mathrm{~s}^{-1}$ & $w, \%$ \\
\hline 1 & 2 & 3 & 4 & 5 & 6 & 7 & 8 \\
\hline \multirow{10}{*}{$\begin{array}{l}\text { Pure } \\
\text { gelatin }\end{array}$} & $\mathrm{H}_{2} \mathrm{O}$ & 1 & 2 & 108 & 109 & 0.79 & 36.8 \\
\hline & & 2 & 3 & 236 & 148 & 1.06 & 63.2 \\
\hline & $\mathrm{HCN}\left(\mathrm{C}_{2} \mathrm{H}_{4}\right)$ & 1 & 3 & 269 & 158 & & 4.3 \\
\hline & $\mathrm{HCN}\left(\mathrm{C}_{2} \mathrm{H}_{4}\right)$ & 2 & 3 & 321 & 174 & & 24.8 \\
\hline & $\mathrm{HCN}\left(\mathrm{C}_{2} \mathrm{H}_{4}\right)$ & 3 & 3 & 404 & 200 & & 14.5 \\
\hline & $\mathrm{HCN}\left(\mathrm{C}_{2} \mathrm{H}_{4}\right)$ & 4 & 3 & 494 & 228 & & 10.3 \\
\hline & $\mathrm{HCN}$ & $5 *$ & 3 & $\begin{array}{c}580-785 \\
(683)\end{array}$ & $\begin{array}{c}255-320 \\
(288)\end{array}$ & $\begin{array}{c}1.78-2.20 \\
(1.99)\end{array}$ & 46.1 \\
\hline & $\mathrm{CO}_{2}$ & 1 & 1 & 243 & 150 & 1.07 & 12.4 \\
\hline & & 2 & 3 & 298 & 167 & 1.19 & 87.6 \\
\hline & $\mathrm{CH}_{4}$ & $1 *$ & 3 & $\begin{array}{c}430-580 \\
(505)\end{array}$ & $\begin{array}{c}208-255 \\
(232)\end{array}$ & $\begin{array}{c}1.46-1.78 \\
(1.62)\end{array}$ & --- \\
\hline \multirow{10}{*}{$\begin{array}{c}\text { A200- } \\
\text { gelatin } \\
(1: 5)\end{array}$} & $\mathrm{H}_{2} \mathrm{O}$ & 1 & 3 & 102 & 107 & 0.78 & 43.9 \\
\hline & & 2 & 3 & 266 & 157 & 1.12 & 56.1 \\
\hline & $\mathrm{HCN}\left(\mathrm{C}_{2} \mathrm{H}_{4}\right)$ & 1 & - & --- & --- & --- & --- \\
\hline & $\mathrm{HCN}\left(\mathrm{C}_{2} \mathrm{H}_{4}\right)$ & 2 & 3 & 327 & 176 & 1.25 & 29.3 \\
\hline & $\mathrm{HCN}\left(\mathrm{C}_{2} \mathrm{H}_{4}\right)$ & 3 & 3 & 411 & 202 & 1.42 & 10.3 \\
\hline & $\mathrm{HCN}\left(\mathrm{C}_{2} \mathrm{H}_{4}\right)$ & 4 & 3 & 494 & 228 & 1.60 & 10.5 \\
\hline & $\mathrm{HCN}$ & $5 *$ & 3 & $\begin{array}{c}608-801 \\
(705)\end{array}$ & $\begin{array}{c}264-325 \\
(295)\end{array}$ & $\begin{array}{c}1.84-2.24 \\
(2.04)\end{array}$ & 49.9 \\
\hline & \multirow[t]{2}{*}{$\mathrm{CO}_{2}$} & 1 & 1 & 259 & 155 & 1.11 & 10.9 \\
\hline & & 2 & 3 & 317 & 173 & 1.23 & 89.1 \\
\hline & $\mathrm{CH}_{4}$ & $1 *$ & 3 & $\begin{array}{c}453-596 \\
(525)\end{array}$ & $\begin{array}{c}215-260 \\
(238)\end{array}$ & $\begin{array}{c}1.51-1.81 \\
(1.76)\end{array}$ & --- \\
\hline
\end{tabular}




\begin{tabular}{|c|c|c|c|c|c|c|c|}
\hline 1 & 2 & 3 & 4 & 5 & 6 & 7 & 8 \\
\hline \multirow{10}{*}{$\begin{array}{c}\text { AMT- } \\
\text { gelatin } \\
(1: 5)\end{array}$} & $\mathrm{H}_{2} \mathrm{O}$ & 1 & 3 & 102 & 107 & 0.78 & 45.7 \\
\hline & & 2 & 3 & 252 & 153 & 1.10 & 54.3 \\
\hline & $\mathrm{HCN}\left(\mathrm{C}_{2} \mathrm{H}_{4}\right)$ & 1 & - & --- & --- & --- & --- \\
\hline & $\mathrm{HCN}\left(\mathrm{C}_{2} \mathrm{H}_{4}\right)$ & 2 & 3 & 321 & 174 & 1.24 & 23.0 \\
\hline & $\mathrm{HCN}\left(\mathrm{C}_{2} \mathrm{H}_{4}\right)$ & 3 & 3 & 411 & 202 & 1.42 & 12.3 \\
\hline & $\mathrm{HCN}\left(\mathrm{C}_{2} \mathrm{H}_{4}\right)$ & 4 & 3 & 494 & 228 & 1.60 & 9.6 \\
\hline & $\mathrm{HCN}$ & $5^{*}$ & 3 & $\begin{array}{c}602-788 \\
(695)\end{array}$ & $\begin{array}{c}262-321 \\
(292)\end{array}$ & $\begin{array}{c}1.82-2.21 \\
(2.02)\end{array}$ & 55.1 \\
\hline & $\mathrm{CO}_{2}$ & 1 & 1 & 246 & 151 & 1.08 & 8.3 \\
\hline & & 2 & 3 & 308 & 170 & 1.21 & 91.7 \\
\hline & $\mathrm{CH}_{4}$ & 1 & 3 & $\begin{array}{c}443-593 \\
(518)\end{array}$ & $\begin{array}{c}212-259 \\
(236)\end{array}$ & $\begin{array}{c}1.49-1.80 \\
(1.65)\end{array}$ & --- \\
\hline \multirow{12}{*}{$\begin{array}{c}\text { A200- } \\
\text { gelatin } \\
(8: 5)\end{array}$} & $\mathrm{H}_{2} \mathrm{O}$ & 1 & 3 & 105 & 108 & 0.79 & 41.7 \\
\hline & & 2 & 3 & 223 & 144 & 1.03 & 32.2 \\
\hline & & 3 & 3 & 288 & 164 & 1.17 & 20.1 \\
\hline & & 4 & 3 & 359 & 186 & 1.32 & 6.0 \\
\hline & $\mathrm{HCN}\left(\mathrm{C}_{2} \mathrm{H}_{4}\right)$ & 1 & - & --- & --- & --- & --- \\
\hline & $\mathrm{HCN}\left(\mathrm{C}_{2} \mathrm{H}_{4}\right)$ & 2 & 3 & 324 & 175 & 1.24 & 37.6 \\
\hline & $\mathrm{HCN}\left(\mathrm{C}_{2} \mathrm{H}_{4}\right)$ & 3 & 3 & 420 & 205 & 1.44 & 5.6 \\
\hline & $\mathrm{HCN}\left(\mathrm{C}_{2} \mathrm{H}_{4}\right)$ & 4 & 3 & 494 & 228 & 1.60 & 7.7 \\
\hline & $\mathrm{HCN}$ & $5 *$ & 3 & $\begin{array}{c}608-785 \\
(697)\end{array}$ & $\begin{array}{c}264-320 \\
(292)\end{array}$ & $\begin{array}{c}1.83-2.20 \\
(2.02)\end{array}$ & 49.1 \\
\hline & $\mathrm{CO}_{2}$ & 1 & 1 & 243 & 150 & 1.07 & 6.1 \\
\hline & & 2 & 3 & 308 & 170 & 1.21 & 93.9 \\
\hline & $\mathrm{CH}_{4}$ & $1 *$ & 3 & $\begin{array}{c}437-605 \\
(521)\end{array}$ & $\begin{array}{c}210-263 \\
(237)\end{array}$ & $\begin{array}{c}1.48-1.83 \\
(1.66)\end{array}$ & --- \\
\hline
\end{tabular}

$E_{\mathrm{a}}-$ activation energy; $k_{0}$ - pre-exponential factor; $n$ - reaction order; $w$ - weight coefficient

* - calculation using the models of activation energy distribution, mean values are given in brackets

One peculiarity should be noted related to the effect of partially hydrophobized silica on the proceeding of gelatin thermal decomposition, namely: the ratio of the compounds with $\mathrm{m} / \mathrm{z} 16$ and 44 formed has changed drastically (Fig. 6). An increase in the amount of $\mathrm{CO}_{2}$ evolved is probably related to the predominance of the reaction of intramolecular decomposition of carboxyl group $\left(-\mathrm{RCOOH} \rightarrow-\mathrm{RH}+\mathrm{CO}_{2} \uparrow\right)$ over the reaction $1^{\mathrm{B}}$.

\section{CONCLUSION}

The silica presence accelerates the thermal degradation of gelatin, decreasing the temperature of both the start and the end of the process. Upon this, as the silica concentration increases, the ending temperature of the polymer thermaloxidative degradation decreases. A decrease in the activation energy of thermal oxidation at the initial stage is probably caused by loosening of the polymer structure as a result of the nanosilica filler embedding. However, this effect is further compensated by an increase in the activation energy of gelatin thermal degradation apparently owing to the multicentered binding with silica surface. Upon silica partial hydrophobization or upon an increase of hydrophilic silica concentration in gelatin film, the activation energy of the polymer thermal-oxidative degradation decreases, this is most likely because of a decreased binding of the macromolecules with the filler surface.

Silica presence practically has no effect on the mechanism of vacuum thermal decomposition of gelatin, since volatile products of this decomposition (mainly $\mathrm{H}_{2} \mathrm{O}, \mathrm{NH}_{3}, \mathrm{C}_{2} \mathrm{H}_{4}, \mathrm{HCN}, \mathrm{CO}_{2}, \mathrm{CH}_{4}$ ) in all the cases are identical. Effect of silica lies in an increase in activation energy for the formation of volatile products of gelatin thermolysis and in change of kinetics and contribution of each component formation into the overall process of thermal decomposition of the polymer.

\section{ACKNOWLEDGEMENT}

The research leading to these results has received funding from the People Programme (Marie Curie Actions) of the European Union's Seventh Framework Programme FP7/2013-2016/ under REA grant agreement No PIRSES-GA2013-612484. 


\title{
Дослідження кремнезем-желатинових матеріалів методами ТГА і ТПДМС
}

\author{
П.О. Кузема, І.В. Лагута, О.М. Ставинська
}

Інститут хімії поверхні ім. О.О. Чуйка Наџіональної академії наук Украӥни вул. Генерала Наумова, 17, Київ, 03164, Украӥна, sci-worker@yandex.иа

\begin{abstract}
Желатинові плівки з масовим співвідношенням кремнезем:желатина 1:5 або 8:5, щуо містять гідрофільний або гідрофільно-гідрофобний кремнезем, було синтезовано $і$ досліджено методами термогравіметричного аналізу і температурно-програмованої десорбиійної мас-спектрометрії. Показано, щчо присутність кремнезему не впливає на механізм термічного розкладання желатини, однак впливає на кінетику ї термолізу у вакуумі та на повітрі, включаючи підвищення енергії активації утворення летких продуктів при вмісті гідрофільного кремнезему близько 17 мас.\%. Гідрофобізачія поверхні кремнезему, а також збільшення концентраціі гідрофільного кремнезему у плівиі з 17 до 62 мас. \% зменшують енергію активації утворення летких продуктів термолізу желатини. Цей ефект пояснено зменшенням зв'язування желатини з кремнеземом або внаслідок заміщення частини силанольних груп поверхні при частковій його гідрофобізації, або за рахунок переважання міжчастинкової взаємодї над взаємодією желатини з кремнеземом при більшій конщентраиї останнього.
\end{abstract}

Ключові слова: желатина, кремнезем, мас-спектрометрія, термогравіметричний аналіз, термоліз

\section{Исследование кремнезем-желатиновых материалов методами ТГА и ТПДМС}

\section{П.А. Кузема, И.В. Лагута, О.Н. Ставинская}

Институт химии поверхности им. А.А. Чуйко Наџиональной академии наук Украинь ул. Генерала Наумова, 17, Киев,03164, Украина, sci-worker@yandex.ua

\begin{abstract}
Желатиновые пленки с массовым содержанием кремнезем:желатин 1:5 или 8:5, содержащие гидрофильный либо гидрофильно-гидрофобный кремнезем, были синтезированы и исследовань методами термогравиметрического анализа и температурно-программированной десорбционной масс-спектрометрии. Показано, что присутствие кремнезема не влияет на механизм термического разложения желатина, однако влияет на кинетику его термолиза в вакууме и на воздухе, включая повышение энергии активаџии образования летучих продуктов при содержании гидрофильного кремнезема около 17 масс. \%. Гидрофобизация поверхности кремнезема, а также увеличение конщентрации гидрофильного кремнезема в пленке с 17 до 62 масс.\% понижают энергию активации образования летучих продуктов термолиза желатина. Этот эффект объяснен уменьшением связывания желатина с кремнеземом либо вследствие замещения части силанольных групп поверхности при частичной его гидрофобизачии, либо за счет превалирования межчастичного взаимодействия над взаимодействием желатина с кремнеземом при более высокой концентрации последнего.
\end{abstract}

Ключевые слова: желатин, кремнезем, масс-спектрометрия, термогравиметрический анализ, термолиз

\section{REFERENCES}

1. Young S., Wong M., Tabata Y., Mikos A.G. Gelatin as a delivery vehicle for the controlled release of bioactive molecules. J. Controlled Release. 2005. 109(1-3): 256.

2. Duconseille A., Astruc T., Quintana N., Meersman F., Sante-Lhoutellie V. Gelatin structure and composition linked to hard capsule dissolution: A review. Food Hydrocolloids. 2015. 43: 360.

3. Santoro M., Tatara A.M., Mikos A.G. Gelatin carriers for drug and cell delivery in tissue engineering. $J$. Controlled Release. 2014. 190: 210.

4. Singh S., Rao K.V.R., Venugopal K., Manikandan R. Alteration in dissolution characteristics of gelatincontaining formulations. Pharm. Technol. 2002. 26(4): 36.

5. Stavinskaya O.N., Laguta I.V., Kuzema P.A. Effect of highly dispersed silica on water absorption of gelatin materials. Prot. Met. Phys. Chem. Surf. 2011. 47: 302. 
6. Zatsepin A.F., Fotiev A.A., Dmitriev I.A. On the assessment of apparent activation energy of exothermic processes by the derivatographic data. Russ. J. Inorg. Chem. 1973. 18: 2883. [In Russian].

7. Kim W.I., Kim S.D., Lee S.B., Hong I.K. Kinetic characterization of thermal degradation process for commercial rubbers. J. Ind. Eng. Chem. 2000. 6(5): 348.

8. Pokrovskiy V.A. Temperature-programmed desorption mass spectrometry. J. Therm. Anal. Calorim. 2000. 62(2): 407.

9. Burdygina G.I., Pron'kina Ye.V., Radugina Yu.Ye., Opel'boim V.V., Kozlov P.V. Effect of low molecular weight substances on the thermal resistance of gelatine. Polym. Sci. U.S.S.R. 1976. 18(6): 1612.

10. Bhaskar G., Ford J.L., Hollingsbee D.A. Thermal analysis of the water uptake by hydrocolloids. Thermochim. Acta. 1998. 322(2): 153.

11. Apostolov A.A., Fakirov S., Vassileva E., Patil R.D., Mark J.E. DSC and TGA studies of the behavior of water in native and cross-linked gelatin. J. Appl. Polym. Sci. 1999. 71(3): 465.

12. Liu W.G., Li F., De Yao K. Thermal and NMR investigation of the change in the states of water caused by volume phase-transition of gelatin gel. Polym. Int. 2000. 49: 1624.

Received 03.09.2015, accepted 31.03.2016 